\title{
The Implications of Employee's Placement on National Development: A Case of Nigeria
}

\author{
Oginni, Babalola Oluwayemi (Corresponding author) \\ Department of Economics and Business Studies \\ Redeemer's University, Ede Osun State, Nigeria \\ E-mail: isomes2011@gmail.com
}

\author{
Erigbe Patience \\ Department of Business Administration \\ Oduduwa University, Ipetu - Modu, Osun State, Nigeria \\ E-mail: perigbe@yahoo.com \\ Ogunlusi 'Femi Christopher \\ Department of Business Administration \\ Bowen University, Iwo, Osun State, Nigeria \\ Laosebikan ‘Sola J. \\ Department of Business Administration \\ Bowen University, Iwo, Osun State, Nigeria
}

Received: November 10, 2017

Accepted: March 8, 2018

Published: April 10, 2018

doi:10.5296/wjbm.v4i1.12982

URL: https://doi.org/10.5296/wjbm.v4i1.12982

\begin{abstract}
The paper examined the implication of employee's placement in national development using federal ministries in Nigeria as focus of the study. It examined the competence of occupants of offices to implement national development plan; examined the relationship between employee's placement and national development as well as challenges confronting employee's placement and national development. This was with a view to providing information on whether employee's placement enhances national development. Purposive
\end{abstract}




\section{Macrothink}

sampling technique was used to select 6 ministries from 28 ministries available and proportional sampling technique was used to obtain 400 respondents from these ministries while random sampling technique was used to administer questionnaire to the respondents. Data collected were analysed using mean, percentages and correlation statistical analysis. The results showed that the choice of occupants into the offices were not based on KSAO; showed positive relationship between employee's placement and national development at 5\% sig. level while God fatherism and quota system were the major challenges confronting employee's placement and national development. However, it was concluded that employee's placement should be based on information provided in job analysis. Thus, recommended that objectivity and KSAO should be the yardstick for employee's placement.

Keywords: Employee's placement, National development, Job analysis, Induction programmes, KSAO 


\section{Introduction}

Employee's placement is one of the functions of human resources management unit and it is usually the end result of recruitment exercise process. It is a follow up to the announcement of an existing vacancy in organisation be it private or public which start with attraction of interest from qualified and competent candidate into the organisation after which the candidates are subjected to selection processes and the chosen ones are engaged as a member of the organisation to carry out tasks designed for the office (Nankervis, Compton, \& Morrisey, 2009). The process of matching skills of an individual with the work's expectation in appropriate way without prejudice is employee's placement. i.e. employees are allowed to function where they have prerequisite skills which may be on the basis of experience or training acquired. This is a task that is often difficult to do on many occasions by human resources unit because of the sensitivity of the unit due to demographic, economic and geographic as well as god fatherism challenges (Fajana, 2002; Sulaiman, Ogunyomi, \& Akosile, 2001; Adewale, 2016). These challenges often placed constraint on the desire of human resources unit to match the man with the job but end up bending the job for the man without recourse to the emerging effect in the long run. The fairness of employee's placement is contingent on an acronym tagged KSAO - Knowledge, Skill, Ability, Other Personal characteristics that will make the individual to perform satisfactorily on the job and where placement is not objectively done at the end of the recruitment exercise in any organisation, performance is always below acceptable level and can mark the beginning of severe loss to the organisation in terms of market share and productivity (Teresa \& James, 2013). Royal and Agnew (2011) added that induction programmes should form part of employee's placement in order to facilitate adjustment to the work and work environment. In the views of Oginni and Faseyiku (2013), employee's placement should derive its strength from job analysis because through job analysis, the nature of the job and synopsis of human elements required can be identified and conduct proper matching of man with the job. Therefore, to attract the most qualified employees and match them to the jobs for which they are best suited is important for the success of any organization. What about the country as a whole? Is attracting the most qualified employees to the jobs for which they are best suited important for the development of the country? The development is measured by improvement in the social welfare of the people through provision of social amenities like quality education, potable water, transportation infrastructure, medical care, etc. which are national development indices (Aluko, 2016).

In the views of Aluko (2016), national development is concerned with social condition of a nation, where the authentic needs of the people are satisfied by the rational and sustainable use of natural resources and systems. To him, utilization of natural resources is based on a technology, which respects the cultural features of the population of a given country. Development in the real sense connotes that citizens of a country have access to employment opportunities, basic services such as education, housing, health services, and nutrition as well as achievement of a positive rate of distribution and redistribution of national wealth (Lawal \& Abe, 2011). Nigerian governments were not left out of the real sense of what national development is all about and this explains why various national development plans have been 
put in place to better the lives of people in the country (Ojo, 2012). According to Wilson (2015), Nigeria experience in developmental plans is relatively youg which began with the Colonial Development Plan (1958-68). Medium-term development plans and national rolling plans were also developed and implemented with mixed results. Other major strategic initiatives such as the Structural Adjustment Programme; the National Economic Empowerment and Development Strategy; the Strategy for Attaining the Millennium Development Goals; and the 7-Point Agenda. The Nigeria Vision 20:2020 expressed the desire of the country to be one of the top 20 economies in the world by 2020. Attainment of the Vision would usher in a high standard of living for its citizens (Ojo, 2012; Adeomo, 2016; Ugochukwu, 2017).

All these were developed by Nigerians for the Nigerian people in order to improve their quality of life. However, the expected results were never realized despite the good intention of the programmes/plans. What could be held responsible - implementation? As adduced forward by many scholars (Williams, 2011). If it is implementation, what is the basis for implementation? It is people. Therefore, the focus of this paper is to examine individuals (people) at various levels of implementing national development plans in relations to the job requirements and skills i.e. employee's placement. This is with a view to understanding the significant of employee's placement in national development.

\subsection{Research Objective}

The main objective of the paper is to examine the implication of employee's placement on national development and achievable through the following specific objectives which were to;

1) Examine competence of occupants of offices to implement plans towards national development.

2) Examine relationship between employee's placement and national development

3) Identify challenges confronting employee's placement and national development

\subsection{Justification for the Research}

The success of any organisation is contingent on the creams of employees in its fold and each of them doing what is known to do best. The only way to ensure this is through appropriate employee's placement (Brand \& Bax, 2002). Dessler (2008) argued that faulty employee's placement results in poor employee performance with negative effect on organisational efficiency, attrition rate, organisational integrity, individual ambitions while proper employee's placement fosters growth, enabling organisational climate, high morale and motivating spirit, maximizes performance, accomplishment of organisational objectives. Therefore, it is worth noting whether inability to actualize the end products of national developmental plans is employee's placement or not.

\section{Literature Review}

The review of literature was based on the two variables in the paper i.e. employee's placement and national development. The employee's placement is independent variable and 
national development is the dependent variable.

\subsection{Employee’s Placement}

Employee's placement is the process by which new employees are assigned to a position where the employee has a reasonable chance for success (Dessler, 2008). To Teresia and James (2013), employee's placement is understood "as the allocation of people to the job" while Kumar and Sharma (2001) viewed employee's placement "as the determination of the job to which an accepted candidate is to be assigned". It can be inferred that employee's placement includes initial assignment of new employees to job and promotion, transfer or demotion of present employees is another form of placement (Oginni \& Faseyiku, 2013).

The process of employee's placement starts with job analysis and any placement that is done in line with this will bring the best out of the employee which will invariably improve overall organisational performance (Adeomo, 2016). The employer advertises to invite applications from candidates for a specific post. The advertisement contains job description and job specifications in detail. The job description will contain necessary information about the job ranging from title, location, responsibilities, duties, equipment etc. while the job specifications do focus on minimum human qualifications needed for the successful candidate to perform satisfactorily. Induction of employees into organisation is the last stage of employee's placement and it is believed to aid quick adjustment and support to work network of an organisation (Oginni \& Faseyiku, 2013). Induction is the process of initiating a new employee into an organisation and acquainting such employee with the details and requirement of the job (Grobler, Warnich, Carrell, Elbert, \& Hartfield, 2006). Buckley and Caple (2008) in support of this argued that a well-done placement with induction process can improve staff confidence and productivity provided that the inducted employees have basic knowledge and skills needed to succeed on the job. The position of Williams (2014) was also in support of this that adequate skills of a job would make knowledge of a job meaningful. However, the views of Adeomo (2016) were not in support of this. To him, the success of an employee in a job is beyond basic knowledge and skills, there is also need for ability and right attitude while Clark (2014) opined that skills are acquired through training which often makes knowledge better but the success of an employee on the job would in addition require more of employeels personality development.

\subsection{Principles of Employee's Placement}

Adewale (2016) identified six (6) basic principles that human resources unit should follow at the time of employee's placement on the job.

1) Job first, man next, should be the principle of the placement. i.e. Man should be placed on the job according to the requirements of the job. The job should not be adjusted according to the qualifications or requirements of the man.

2) Job should be offered to the person according to his qualification. This should neither be higher nor be lower than the qualification.

3) Employees irrespective of cadre, should have holistic understanding of prevailing 
working conditions at all time with associated penalties if violated.

4) From the day of assumption of duty, employee's sense of loyalty and cooperation should be developed and make to understand the linkage of his responsibility towards the organization.

5) The placement should have been decided in advance prior to the joining date of the newly selected person.

6) Placement may be temporary where there is need to conduct training exercise for the new employee, the outcome of the training should be the deciding factor to inform where to place the new employee on permanent basis.

Where the principles are adhered to strictly, placement will help to improve the morale of employees as well as utilizing the capacity of employees fully. In addition, placement reduces labour turnover, absenteeism and the accident rate. Also, facilitate employee adjustment to the work environment of the organization effectively and ensure that performance of the employee will not be hampered. The major problem of employee's placement is that recruiters tend to look at the individuals and not the job (Gomez-Mejia, Balkin, \& Cardy, 2012).

\subsection{National Development}

National development is the ability of a nation to improve the lives of its citizens (Akindele, Oginni, \& Agada, 2013). In the views of Ogai (2007) national development is gradual manifestation of positive changes in the economic, industrial, political, social, cultural and administrative life of country. This position buttressed the views of Naomi (1995) that development involves not only economic growth but also some notion of equitable distribution, provision of health care, education, housing and other essential services all with a view to improving the individual and collective quality of life. The implication is that national development has to do with increase, upgrade in the living standard of the citizenry, national economy, structure of the legal system etc. and the overall objective of national development is to improve the lives of the citizens in question within the context of a growing economy and an emphasis on the good of the community as a whole (Lawal \& Abe, 2011).

On the basis of the positions of Baddell (2014) and Johnson (2015) in Aluko (2016) national development is the ability of a country to improve the social welfare of the people, for example, through provision of social amenities like good education, infrastructure, medical care and social services as well as development in social, political, economic, emotional, linguistic and cultural fields. It can be deduced that the core areas of national development are education, housing, health care, power, road, employment etc. i.e. a country with improvement in quality of education, affordable housing for all the citizens, good health care delivery, constant supply of electricity, good network of roads, reduction in unemployment rate can be said to enjoy considerable national development and vice versa. Therefore, the implication is that for any country to attain national development objective, action plans should be geared towards these core areas of development indices. 
Before independent and after independent of Nigeria, successive government in Nigeria were never in the dark about the need for national development plans to usher in quality of life for citizens at all sphere of life and this explained various developmental plans that have been put in place as shown in the below table 1;

Table 1. Various national development plans

\begin{tabular}{|c|c|c|}
\hline Development Plans & Period & Objectives/Targets of Plans \\
\hline $\begin{array}{l}\text { Pre-National } \\
\text { Development Era }\end{array}$ & $\begin{array}{l}\text { (i) } 1946-1955 \\
\text { (ii) } 1955-60-62\end{array}$ & $\begin{array}{l}\text { Uncoordinated or unrelated to any overall economic } \\
\text { target. }\end{array}$ \\
\hline $\begin{array}{l}\text { First National } \\
\text { Development }\end{array}$ & $1962-1968$ & $\begin{array}{l}\text { To encourage the assemblage of agricultural produce for } \\
\text { export purpose. }\end{array}$ \\
\hline $\begin{array}{l}\text { Second National } \\
\text { Development }\end{array}$ & $1970-1974$ & $\begin{array}{l}\text { Post-war reconstruction, restoring productive capacity, } \\
\text { overcoming critical bottlenecks and achieving } \\
\text { self-reliance (i.e. meant to achieve a united, just, strong } \\
\text { and self-reliant nation). }\end{array}$ \\
\hline $\begin{array}{l}\text { Third National } \\
\text { Development }\end{array}$ & $1975-1980$ & $\begin{array}{l}\text { Emphasized the need to reduce regional disparities in } \\
\text { order to foster national unity through the adoption of } \\
\text { integrated rural development. }\end{array}$ \\
\hline $\begin{array}{l}\text { Fourth National } \\
\text { Development }\end{array}$ & $1981-1985$ & $\begin{array}{l}\text { A civilian government Development Plan which } \\
\text { emphasized among other things the need for balanced } \\
\text { development of different sectors of the economy and the } \\
\text { various geographic areas of the country. }\end{array}$ \\
\hline $\begin{array}{l}\text { Post-Fourth } \\
\text { Development Plan } \\
\text { Period }\end{array}$ & $1985-1987$ & $\begin{array}{l}\text { Establishment of the Directorate for Food, Roads and } \\
\text { Rural Infrastructure (DFRRI) in } 1985 \text { for the purpose of } \\
\text { providing rural infrastructure in the countryside. }\end{array}$ \\
\hline $\begin{array}{l}\text { Fifth National } \\
\text { Development Plan }\end{array}$ & $1988-1992$ & $\begin{array}{l}\text { To devalue the Naira, remove import licenses, reduce } \\
\text { tariffs, open the economy to foreign trade, promote } \\
\text { non-oil exports through incentives and achieve national } \\
\text { self-sufficiency in food production. Later } \\
\text { ABANDONED. }\end{array}$ \\
\hline $\begin{array}{l}\text { Three-year Rolling } \\
\text { Plan }\end{array}$ & 1990-1992 & $\begin{array}{l}\text { To reduce inflation and exchange rate instability, } \\
\text { maintain infrastructure, achieve agricultural } \\
\text { self-sufficiency, and reduce the burden of SAP. }\end{array}$ \\
\hline $\begin{array}{l}\text { Era of National } \\
\text { Planning Commission } \\
\text { of Nigeria and their } \\
\text { Programmes }\end{array}$ & 1992/93-1995 & $\begin{array}{l}\text { Formulation of medium term and long term economic } \\
\text { and development plans for the nation, advising Federal } \\
\text { government on matters relating to National } \\
\text { Development and overall management of the national } \\
\text { economy. }\end{array}$ \\
\hline The Vision 2010 & $1996-1997$ & $\begin{array}{l}\text { To develop a blueprint that will transform the country } \\
\text { and place it firmly on the route to becoming a developed } \\
\text { nation by the year } 2010 \text {. It was abandoned }\end{array}$ \\
\hline
\end{tabular}




\begin{tabular}{|l|l|l|}
\hline The Vision 20: 2020 & $1999-2007$ & $\begin{array}{l}\text { The policy was articulated to make Nigeria one of the } \\
\text { twenty largest economies in the world by the year 2020 } \\
\text { and to consolidate its leadership role in Africa and } \\
\text { establish itself as a significant player in the global } \\
\text { economic and political arena. }\end{array}$ \\
\hline The Vision 2015 & $2002-2005$ & $\begin{array}{l}\text { The MDGs are commitment by the UN to establish } \\
\text { peace and a healthy global economy by focusing on } \\
\text { major issues like poverty, children's health, } \\
\text { empowerment of women and girls, sustainable } \\
\text { environment, disease, and development. }\end{array}$ \\
\hline Seven - Point Agenda $2007-2009$ & $\begin{array}{l}\text { Focus on the strategic areas of Nigerian needs to usher } \\
\text { in development that would give citizens sense of } \\
\text { responsibilities to the government and enhance their } \\
\text { quality life of living i.e. Transportation, Power and } \\
\text { Energy, Food Scarcity, National Security, Education, } \\
\text { Land Tenure Reforms, Wealth Creation }\end{array}$ \\
\hline Transformation & $2011-2015$ & $\begin{array}{l}\text { A medium-term development strategy to speed up the } \\
\text { actualization of the vision } 20: 2020, \text { and as such for the } \\
\text { actualization of the federal government's economic } \\
\text { growth agenda }\end{array}$ \\
\hline
\end{tabular}

Source: Georgina, O. U. (2014). The Economic Implications of National Development Plans: The Nigerian Experience (1946-2013). Journal of Developing Country Studies, 4(9), 1-5.

In spite of serial developmental plans put in place by successive governments to generate and create meaningful developments, the current state of developments in the country is not in agreement this; many reasons have been identified to be responsible such as communalism, ethnic fanaticism, regionalism, social disparity, economic inequalities, religious fanaticism, national character, political instability (Georgina, 2014; Ojo, 2012). There had not been any mention of employee's placement to national development.

\section{Methodology}

Data were collected through the use of multi - stage sampling technique from the respondents who were mainly federal civil servants. Purposive sampling was used to choose 6 federal ministries from 28 federal ministries as the sample to include Education, Power and Steel, Health, Works and Housing, Commerce and Industries, Labour and Productivity. Proportional sampling was used to obtain 400 respondents as the sample size and random sampling was used to administer the questionnaire to the respondents. Out of 400 copies of questionnaire administered over a period of 8 months, 326 copies were collected back and 268 were found useful for analytical purpose, thus representing $67 \%$ response rate. The questionnaire was in conformity with Likert's five points rating scale (strongly agree to strongly disagree) and consists of different questions on 4 employee's placement dimensions such as skills, knowledge, ability and other Personal characteristics (SKAO). Data were analysed through 
mean and percentages (descriptive statistics) with bench mark criterion set at weighted mean of $\geq 3.0$ for agreement and weighted mean of $\leq 3.0$ for disagreement and correlation (inferential statistics).

\section{Analysis and Interpretations}

Table 2. Demographic characteristics of the respondents

\begin{tabular}{|c|c|c|c|}
\hline Variables & Categories & Count & Percentage \\
\hline Gender & $\begin{array}{l}\text { Male } \\
\text { Female } \\
\text { Total }\end{array}$ & $\begin{array}{l}159 \\
109 \\
268\end{array}$ & $\begin{array}{l}59 \% \\
41 \% \\
100 \%\end{array}$ \\
\hline Age & $\begin{array}{l}\text { Less than } 25 \text { years } \\
25 y r s-35 y r s \\
36 y r s-46 y r s \\
47 y r s-57 y r s \\
58 y r s \text { and above } \\
\text { Total }\end{array}$ & $\begin{array}{l}45 \\
51 \\
43 \\
73 \\
56 \\
268\end{array}$ & $\begin{array}{l}17 \% \\
19 \% \\
16 \% \\
27 \% \\
21 \% \\
100 \%\end{array}$ \\
\hline Marital Status & $\begin{array}{l}\text { Single } \\
\text { Married } \\
\text { Widow } \\
\text { Widower } \\
\text { Total } \\
\end{array}$ & $\begin{array}{l}43 \\
178 \\
31 \\
16 \\
268 \\
\end{array}$ & $\begin{array}{l}16 \% \\
66 \% \\
12 \% \\
6 \% \\
100 \% \\
\end{array}$ \\
\hline $\begin{array}{l}\text { Educational } \\
\text { level }\end{array}$ & $\begin{array}{l}\text { WASC 'O' level } \\
\text { NCE/ND } \\
\text { B.Sc. / HND } \\
\text { M.Sc./ M.A } \\
\text { Ph. D. } \\
\text { Total } \\
\end{array}$ & $\begin{array}{l}68 \\
21 \\
130 \\
47 \\
2 \\
268\end{array}$ & $\begin{array}{l}25 \% \\
8 \% \\
48 \% \\
18 \% \\
1 \% \\
100 \% \\
\end{array}$ \\
\hline $\begin{array}{l}\text { Length of } \\
\text { service }\end{array}$ & $\begin{array}{l}\text { Less than } 10 \mathrm{yrs} \\
10 \mathrm{yrs}-20 \mathrm{yrs} \\
21 \mathrm{yrs}-30 \mathrm{yrs} \\
31 \mathrm{yrs} \text { above } \\
\text { Total }\end{array}$ & $\begin{array}{l}37 \\
51 \\
102 \\
78 \\
268 \\
\end{array}$ & $\begin{array}{l}14 \% \\
19 \% \\
38 \% \\
29 \% \\
100 \%\end{array}$ \\
\hline
\end{tabular}

Source: Field Survey, 2017.

From table 2, it showed that majority of the respondents were male with 159 respondents representing $59 \%$ of the total respondents. The majority of the respondents were in the age range of 47 - 57years with 73 respondents representing $27 \%$ followed by 58years and above. This showed that the respondents are matured to understand the essence of assigning employees to a job. For the marital status, $66 \%$ of the respondents were married signifying majority of the respondents which implies height of responsibility with sound mind of judgement without fear of contradiction. The table also showed that majority of the 
respondents has first degree with 130 respondents representing $48 \%$ followed by respondents with secondary school certificate. The implication is that respondents are knowledgeable enough to understand contents of the questionnaire and give their candid opinion. For the length of service, majority of the respondents were within the range of $21 \mathrm{yrs}-30 \mathrm{yrs}$ with 102 respondents representing $48 \%$ to imply that respondents have stayed long enough on the job to experience posting of personnel from one duty post to another.

Table 3. Competency and relationship analyses

\begin{tabular}{|l|l|l|l|l|l|l|l|}
\hline S/N & Employee's Placement Variables & N & Mean & Mean Rank & Remarks & B & ț \\
\hline 1 & Knowledge & 268 & 2.56 & 4 & D & 0.423 & 4.651 \\
\hline 2 & Skills & 268 & 2.67 & 3 & D & 0.246 & 3.837 \\
\hline 3 & Abilities & 268 & 3.45 & 1 & A & 0.133 & 3.552 \\
\hline 4 & Other Personal Characteristics & 268 & 3.18 & 2 & A & 0.239 & 3.668 \\
\hline
\end{tabular}

Source: Field Study Analysis, 2017 and A = Agreement while D = Disagreement.

The summary of all the questions under Knowledge focused on the in-depth understanding of the job, that of Skill laid emphasis on the expertise of the candidate concerning the job and Abilities on the capacity to achieve goals expected while Other personal characteristics focused on the endowment of individual to meet environmental demands of the job. Abilities was rank first, followed by other personal characteristics, skills and knowledge.

From table 3, it is evident that the occupants of these offices do not have knowledge and skills required to do the job although have the abilities and other personal characteristics. The implication is that the occupants of these offices cannot really propel act or map out strategies that will foster the implementation of the national developmental plans due to deficiency in operational knowledge and skills. Abilities and Other personal characteristics can only be meaningful in the implementation of the national developmental plans where the knowledge and skills are adequate. The table also showed the contribution of employee's variables in terms of potency to national development where knowledge is vital in order to bring out the desire development followed by skills, abilities and other personal characteristics have significant effect on national development at 0.05 Significant level.

Table 4. Measuring extent of relationship between employee's placement and national development

\begin{tabular}{|l|l|l|l|l|l|}
\hline & \multicolumn{5}{|c|}{ Coefficient } \\
\hline Variables & $\mathbf{R}$ & $\mathbf{R}^{2}$ & $\mathbf{F}_{\text {cal }}$ & $\mathbf{F}_{\text {tab }}$ & $\mathbf{t}-$ Sig \\
\hline EP and ND & $\mathbf{0 . 6 4 3}$ & $\mathbf{0 . 7 4 2}$ & $\mathbf{6 . 4 3 2}$ & $\mathbf{3 . 8 6 5}$ & $\mathbf{0 . 4 3 2}$ \\
\hline
\end{tabular}

Source: Field Study, 2017 (EP = Employee's Placement and ND = National Development).

Table 5 showed that $\mathrm{R}=0.643, \mathrm{R}^{2}=0.742, \mathrm{~F}_{\text {cal }}=6.432, \mathrm{~F}_{\mathrm{tab}}=3.865$ and $\mathrm{t}-$ sig. $=0.432$. The 
model summary showed a linear correlation relationship between the variables (independent and dependent) because $\mathrm{R}$, the predictor variable has value of 0.643 which showed that there exists a strong positive correlation between employee's placement and national development. i.e. an increase in the employee's placement will bring about increase national development. $\mathrm{R}^{2} .=0.742$ which was the coefficient of multiple determination showed that employee's placement explains $74 \%$ of the total variation in national development. The remaining $26 \%$ was explained by other variables not mentioned in the model. This further confirms that there exists a strong linear relationship. Also, the value of $F_{\text {cal }}=6.432$ and $F_{\text {tab }}=3.865$ which

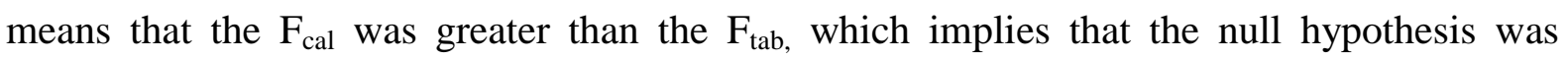
rejected while alternative hypothesis was accepted. It showed that there is significant relationship between the independent variables (employee's placement) and dependent variables (national development).

Table 5. Kendal's test mean rank and coefficient values of challenges for employee's placement in national development

\begin{tabular}{|c|c|c|c|c|c|c|c|c|}
\hline $\mathbf{S} / \mathbf{N}$ & Variables & $\mathbf{N}$ & Mean & Rank & Kendal's W $\mathbf{W}^{\mathrm{a}}$ & B & $\mathbf{T}$ & Potency \\
\hline 1 & Quota System & 268 & 4.78 & 4 & \multirow[t]{4}{*}{0.783} & 0.304 & 4.235 & 2 \\
\hline 2 & Federal Character & 268 & 4.47 & 2 & & 0,183 & 2.331 & 4 \\
\hline 3 & God 'Fatherism' & 268 & 5.24 & 1 & & 0.415 & 6.123 & 1 \\
\hline 4 & Unemployment & 268 & 4.68 & 3 & & 0.167 & 3.152 & 3 \\
\hline
\end{tabular}

Source: Field Study, 2017.

Table 5 showed result for Kendal test mean ranking and coefficient values of challenges for employee's placement in national development. The results showed that God fatherism (5.24) was ranked first in order of agreement followed by quota system (4.78), unemployment (4.68), federal character (4.47), and with Kendall's W result as $\mathrm{W}^{\mathrm{a}}=0.783$ which signified strong outcome in terms of agreement concordance. The coefficient values showed that God fatherism was the potent variable among the challenges variables, next was quota system, unemployment and federal character. The overall implication is that God fatherism and quota system are the major challenges confronting employee's placement in national development.

\section{Discussion of Findings}

From the demographic data, male respondents were predominant, the work force is not ageing and there is stability in the work force while the ministries also have more of graduates. From the data analysis in table 3, employees in the ministries believed that occupants of positions to implement national development plans have the ability and other personal characteristics needed to implement these plans but do not have adequate knowledge and skills required in these ministries. This finding was supported by the works of Buckley and Caple (2008); Williams (2014); Clark (2014) and Adeomo (2016) as they laid emphasis on knowledge, skills, ability and training as well as right attitude and personality development. However, a link of the result to the positions of Buckley and Caple (2008) and Williams (2014) will imply that the absence of adequate knowledge and skills on the part of occupants of positions to implement 
various national development plans would mean non - performance on their part. Table 4 revealed that the relationship that exists between employee's placement and national development is positively strong i.e. increase in employee's placement will have a corresponding increase in national development. This finding was supported by the position of Adesomo (2016) where he opined that employee's placement should be based on job descriptions and human requirements. The views of Adewale (2016) also corroborated this result that Job first, man next, should be the principle of the placement. i.e. Man should be placed on the job according to the requirements of the job. The job should not be adjusted according to the qualifications or requirements of the man. From table 5, God fatherism was found to be the most potent contributor to national development while quota system, federal character and unemployment were also contributors to the challenges of employee's placement in national development. The implication of the result is that merit, experience and hard work do not matter if God fatherism and quota system are in use especially when it comes to appointments. It is contrary to what Max Weber (1864 1920) said, that employees should be hired and promoted based on merit and expertise. The practice of God fatherism, quota system, federal character and unemployment will promote mediocre in place of merit and it is evident in the intensity experienced in lobbying each time there is a vacancy to be filled at national level. This outcome was in agreement with the result obtained in table 3 that occupants of positions to implement national development plans do not have adequate knowledge and skills required for the job as many got there through God fatherism and quota system.

\section{Conclusion}

The objective of the paper was to examine the implications of employee's placement on national development with reference to Nigeria as a case study. It was evident in Nigeria that there had been series of plans to ensure quality of life for all the citizens in all its ramifications. However, the expected developments could not be attained as at today despite over 60 years of development plans because there had been constant violation of employee's placement principles. Knowledge and skills required for job holders were not in consonant agreement with the requirements of the job while abilities and characteristics needed to meet environment challenges for success on job were out of order. In addition, employee's placement has further been hampered by the policy of national outlook which set aside merit and reward mediocre as evident in the challenges confronting employee's placement. Therefore, under present arrangement, those plans laid out to usher in national development that will make citizens to have access to quality education, good health care delivery, absence of epileptic supply of electricity, durable transportation system, low cost housing etc. cannot be realized since the human elements to ensure the strategic implementation of these programmes are somewhat a mismatch. i.e. Nigeria cannot experience national development as long as employee's placement is subjected to national outlook wherein federal character, quota system and God fatherism are the guiding principles in employment processes.

\section{Recommendations}

On the basis of the conclusion, the following are therefore recommended to ensure that;

1) Employees are assigned to a position where the employee has a reasonable chance for 
success with emphasis on KSAO

2) Employment on the basis of national outlook that calls for federal character and quota system practices in employment decision making should be jettisoned.

3) Job first, man next, should be the principle of the placement. I.e. Man should be placed on the job according to the requirements of the job. The job should not be adjusted according to the qualifications or requirements of the man.

4) The practice of sacrificing meritocracy and the expense of mediocrity should be discouraged at all levels.

\section{References}

Ademola, O. (2016b). X-ray of National Development Programmes in Nigeria. Ibadan: Ayeni Publishing House.

Ademola, O. (2016c). The Management of Human Resources at Work. Ibadan: University Press.

Adewale, O. (2016a). The Policies and Practices of Human Resources Management in the $21^{\text {st }}$ Century. Lagos, Kayus Print Ltd.

Akindele, R. I., Oginni, B. O., \& Agada, S. A. (2013). National Development and Political Corruption in Nigeria: Leadership at Crossroad. European Journal of Business and Management, 5(9), 170-179

Aluko, J. (2016). The Concept of Development in Nigeria. Lagos: Shecom Ltd.

Brand, M., \& Bax, E. (2002). Strategic HRM for SMEs: Implications for firms and policy. Education and Training, 44, 455-463. https://doi.org/10.1108/0040091020449295

Buckley, R., \& Caple, J. (2008). The Theory and Practice of Training (5 $5^{\text {th }}$ ed.). London: MPG Books Ltd.

Clark, P. (2014). Human Resource Training and Development. Singapore, Thomson South Western.

Dessler, G. (2008). Human Resource Management (11th ed.). Upper Saddle River, New Jersey, Pearson Education

Fajana, S. (2002). Human Resource Management, An introduction. Labofin and company, Lagos.

Georgina, O. U. (2014). The Economic Implications of National Development Plans: The Nigerian Experience (1946-2013). Journal of Developing Country Studies, 4(9), 171-179.

Gomez-Mejia, L. R., Balkin, D. B., \& Cardy, R. L. (2012). Managing Human Resources. Pearson Education, Inc. USA.

Grobler, P., Warnich, S., Carrell, M. R., Elbert, N. F., \& Hatfiel, R. D. (2006). Human resource management in South Africa (3rd ed.). London: Cengage Learning EMEA. 


\section{Macrothink}

World Journal of Business and Management ISSN 2377-4622 2018, Vol. 4, No. 1

Kavoo-Linge, T., \& James, K. K. (2013). The Effect of Placement Practices on Employee Performance in Small Service Firms in the Information Technology Sector in Kenya. International Journal of Business and Social Science, 4(15), 213-219.

Kumar, A., \& Sharma, R. (2001). Personnel Management Theory and Practice. Washington DC: Atlantic Publishers.

Lawal, T., \& Abe, O. (2011). National Development in Nigeria, Issues, Challenges and Prospects. Journal of Public Administration and Policy Research, 3(9), 237-241.

Nankervis, A., Compton, R., \& Morrisey, B. (2009). Effective Recruitment and Selection Practices (5th ed.) New South Whales: CCH Australia Limited.

Naomi, O. (1995). Towards an integrated view of Human Rights. Hunger Teach Net, 6(3), 6-7.

Ogai, J. O. (2007). An Analysis of the Concepts of Development and Underdevelopment. In O. Uwakwe (Ed.), Communication National Development (2nd ed.).

Oginni, B. O., \& Faseyiku, 1. O. (2013). Fundamental of Human Capital Management, A process approach. Somolu, Lagos: Mankore Print Ltd.

Ojo, O. E. (2012). Constraints on Budgeting and Development Plan Implementation in Nigeria: An Overview. European Journal of Sustainable Development, 1(3), 445-456.

Royal, M., \& Agnew, T. (2011). The Enemy of Engagement. New York: AMACOM.

Sulaimon, A. A., Ogunyomi, P. O., \& Akosile, O. K. (2001). Human Resources Management. Lagos: Adeola Printing Press Ltd.

Ugochukwu, I. (2017). Principles and Practices of Development Administration. Benin City, Lagson Publishing Press.

Williams, R. G. (2011). Policy Formulation and Implementation - The human factor. Interdisciplinary Journal of Management Studies, 4(7), 102-112

Williams, R. G. (2014). Employee's Competency and Peter's Principle, International Journal of Business Research, 2(5), 72-81.

Wilson, A. K. (2015). Democracy and National Development: A Siamese Twin. Public Lecture Series, Obafemi Awolowo University, Ile - Ife.

\section{Copyright Disclaimer}

Copyright for this article is retained by the author(s), with first publication rights granted to the journal.

This is an open-access article distributed under the terms and conditions of the Creative Commons Attribution license (http://creativecommons.org/licenses/by/3.0/). 